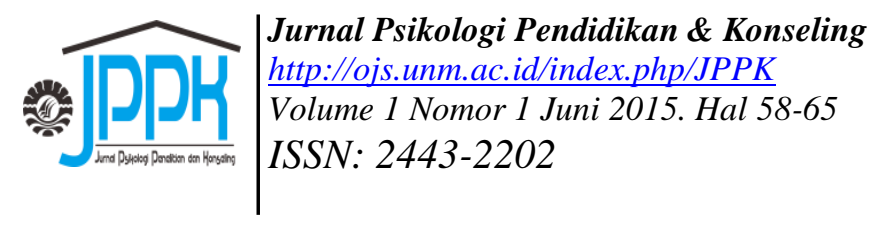

\title{
EFEKTIVITAS BIMBINGAN KARIER UNTUK PENINGKATAN CORE WORK SKILLS MAHASISWA
}

\author{
Sahril Buchori \\ Bimbingan dan Konseling, Universitas Negeri Makassar \\ email: buchori_bk@yahoo.co.id \\ Ilfiandra \\ Bimbingan dan Konseling, Universitas Pendidikan Indonesia \\ email: ilfiandra_upi@yahoo.com
}

\begin{abstract}
The purpose of this research was to bring out career guidance program to enhance students' core work skills. This research applied quantitative approach and quasi experiment method with pretest and posttest design. The instruments used in this research were questionnaire and interview. The data analysis applied t-test of core work levels between before and after attending the career guidance program. The findings of this research showed that half of last semester students were at the medium level of core work skills and half of them were at the high level. Referred to the 20 indicators of core work skills, 10 were at the high level and 10 were not optimally mastered yet. The research findings revealed that the career guidance program is effective to enhance students' core work skills. The enhancement can be identified through the 20 indicators of core work skills, 18 increased effectively and 2 did not increase effectively after the treatment.
\end{abstract}

Keywords: Career guidance and core work skills

\begin{abstract}
Abstrak: Tujuan penelitian ini adalah menghasilkan program bimbingan karier untuk peningkatan core work skills mahasiswa. Penelitian ini menggunakan pendekatan kuantitatif dan metode eksperimen kuasi dengan desain pretest dan posttes. Alat instrumen yang digunakan adalah kuesioner dan wawancara. Analisis data menggunakan uji perbedaan dua rata-rata (uji-t) tingkat core work skills sebelum dan setelah mengikuti program bimbingan karier. Hasil studi pendahuluan menunjukkan tingkat core work skills sebagian mahasiswa semester akhir berada pada kategori sedang dan setengahnya lagi berada pada kategori tinggi. Ditinjau dari 20 indikator core work skills, 10 cenderung berada pada kategori Tinggi dan 10 pada kategori Sedang atau belum dikuasai secara optimal.Hasil penelitian menunjukkan program bimbingan karier efektif untuk peningkatan core work skills mahasiswa. Peningkatan dapat dilihat dari 20 indikator core work skills, 18 indikator efektif meningkat dan 2 indikator tidak efektif meningkat setelah pemberian perlakuan.
\end{abstract}

Kata Kunci: Bimbingan karier dan core work skills

\section{PENDAHULUAN}

Pendidikan adalah daya upaya yang terencana untuk mewujudkan suasana belajar dan proses pembelajaran agar peserta didik secara aktif mengembangkan potensi dirinya untuk memiliki kekuatan spiritual keagamaan, pengendalian diri, kepribadian, kecerdasan, akhlak mulia, serta keterampilan yang diperlukan dirinya dan masyarakat. Hal ini sesuai dengan pendapat Ki Hajar Dewantara (Yana, 2013) pendidikan sebagai daya upaya memajukan budi pekerti, pikiran serta jasmani anak, agar dapat memajukan kesempurnaan hidup, yaitu hidup dan menghidupkan anak yang selaras dengan alam dan masyarakatnya.

Pendidikan bertujuan agar peserta didik memiliki daya cipta (kognitif), daya rasa 
(afektif), dan daya karsa (konatif). Singkatnya, "educate the head, the heart, and the hand" (Yana, 2013) pendidikan bertujuan meningkatkan pengetahuan anak didik tentang apa yang dipelajarinya, mengasah rasa untuk meningkatkan pemahaman tentang apa yang diketahuinya, serta meningkatkan kemampuan atau keterampilan untuk melaksanakan apa yang dipelajarinya. Konsep pendidikan $\mathrm{Ki}$ Hajar Dewantara dapat diimplementasikan dalam semboyan yang dikenal sebagai semboyan pendidikan Indonesia yaitu:"Ing ngarso sung tulodo, Ing madya mangun karso, Tutwuri handayani" (Yana, 2013). Artinya, pendidik hendaknya menjadi teladan di depan peserta didik, membangun semangat, berswakarya, berkreasi bersama peserta didik dan mendorong serta mengarahkan peserta didik agar berani berjalan di depan dan sanggup bertanggung jawab.

Konsep pendidikan dalam undang-undang No. 20 Tahun 2003 tentang Sistem Pendidikan Nasional sebagai usaha sadar terencana untuk mewujudkan suasana belajar dan proses pembelajaran agar peserta didik secara aktif mengembangkan potensi dirinya untuk memiliki kekuatan spiritual keagamaan, pengendalian diri, kepribadian, kecerdasan, akhlak mulia, serta keterampilan yang diperlukan dirinya, masyarakat, bangsa, dan negara. Dalle (Rahman, 2012) mengemukakan bahwa pendidikan adalah usaha sadar yang dilakukan oleh keluarga, masyarakat, dan pemerintah melalui kegiatan pengajaran, bimbingan, pelatihan dan penelitian, yang berlangsung di sekolah dan di luar sekolah atau dalam bentuk pendidikan formal dan non formal, sepanjang hayat untuk mempersiapkan peserta didik agar dapat memainkan peran dalam berbagai lingkup kehidupan secara tetap untuk masa yang akan datang. Sebagai contoh pendidikan formal dilaksanakan mulai dari pendidikan prasekolah atau pendidikan anak usia dini (berupa taman kanak-kanak, play group dan sebagainya), sekolah dasar, sekolah menengah, sampai pada perguruan tinggi.

Salah satu jenjang pendidkan formal adalah pendidikan tinggi yang merupakan tingkat akhir pendidikan formal sebelum memasuki dunia kerja. Perguruan tinggi memiliki peran penting dalam mengembangkan potensi peserta didik berupa sikap mental, keterampilan, kecerdasan, dan wawasan yang diperlukan bagi lulusan untuk memasuki dunia kerja. Pada
Peraturan Pemerintah (PP) nomor 19 tahun 2005 tentang Standar Nasional Pendidikan bab V pasal 26 dijelaskan standar kompetensi lulusan pada satuan pendidikan tinggi bertujuan untuk mempersiapkan peserta didik menjadi anggota masyarakat yang berakhlak mulia, memiliki pengetahuan, keterampilan, kemandirian, dan sikap untuk menemukan, mengembangkan, serta menerapkan ilmu, teknologi, dan seni yang bermanfaat bagi kemanusiaan.

Menurut Pandang dkk. (2010, hlm. 73) untuk dapat sukses dalam dunia kerja, peserta didik atau lulusan perguruan tinggi perlu memiliki berbagai keterampilan yang dibutuhkan dunia kerja sehingga dapat memiliki keyakinan diri yang lebih kuat untuk memasuki dunia kerja. Salah satu keterampilan utama yang dibutuhkan oleh semua jenis pekerjaan berupa core work skills. Core work skills membantu individu atau peserta didik untuk memahami pasar kerja, membuat pilihan yang lebih tepat tentang pilihan mereka dalam pendidikan, pelatihan, upah kerja, wirausaha, koperasi sehingga meningkatkan dan mengamankan kualitas pekerjaan yang lebih baik, serta meningkatkan produktivitas dan pendapatannya. Membantu peserta didik menjadi warga negara yang lebih baik dan memberikan kontribusi kepada masyarakat dan bangsa (Brewer, 2013, hlm. 5).

International Labour Organization (ILO) (Brewer, 2013, hlm. 6) mendefinisikan core work skills sebagai keterampilan, pengetahuan dan kompetensi yang meningkatkan kemampuan pekerja untuk mengamankan dan mempertahankan pekerjaan, kemajuan di tempat kerja dan mengatasi perubahan, mendapatkan pekerjaan lain jika ingin atau telah diberhentikan dan lebih mudah masuk ke dalam pasar kerja di berbagai periode siklus kehidupan. Hasil penelitian di Northwest U.S menunjukkan bahwa keterampilan kerja atau core work skills penting untuk diajarkan oleh lembaga pendidikan sehingga peserta didik dapat lebih baik dan lebih siap untuk dapat sukses di tempat kerja, Cotton (Ju dkk. 2012, hlm. 30). Penelitian Wijayanti dan Zulaifah (2008, hlm. 15) menunjukkan efikasi core skills atau core work skills memberikan pengaruh yang sangat signifikan. Hal tersebut berarti efikasi core skills subjek mempengaruhi kesiapan kerja subjek itu sendiri, hal ini dapat dilihat bahwa semakin tinggi efikasi core skills maka semakin tinggi pula kesiapan kerja yang dimiliki oleh kebanyakan subjek. 
Salah satu elemen pendidikan di perguruan tinggi yang dipandang strategis dalam memfasilitasi pengembangan core work skills adalah program bimbingan karier bagi mahasiswa. Pelayanan bimbingan karier merupakan salah satu dari empat bidang pelayanan bimbingan konseling di perguruan tinggi. Keempat bidang yang dimaksud, adalah bimbingan pribadi, bimbingan sosial, bimbingan pembelajaran, dan bimbingan karier, Prayitno (Pandang dkk. 2010, hlm. 4).

Hasil survey terhadap core work skills mahasiswa prodi Manajemen UPI, diperoleh gambaran pada 40 mahasiswa menunjukkan kategori Sangat Tinggi (14,24\%), Tinggi $(33,75 \%)$, Sedang $(41,43 \%)$, Rendah $(10,20 \%)$, dan Sangat Rendah $(0,38 \%)$. Berdasarkan hasil survey core work skills, hampir setengah atau $41,43 \%$ mahasiswa semester akhir prodi Manajemen masih berada pada kategori sedang dan hanya $14,24 \%$ yang berada pada kategori sangat tinggi. Hal ini menandakan tingkat core work skills mahasiswa masih terbilang minim untuk dapat suskses dalam dunia kerja. Namun jika dilihat dari 20 jenis core work skills, tingka core work skills mahasiswa berada pada tiga kategori yaitu terdapat 1 cenderung berada pada kategori sangat tinggi, 9 pada kategori tinggi dan 10 pada kategori sedang. Hal ini menandakan jenis core work skills mahasiswa berada pada tingkatan yang bervariasi, setengah dari jenis core work skills yang dimiliki mahasiswa telah memadai dan setengah yang lainnya masih berada pada kategori yang belum memadai.

Fakta ini menunjukkan tingkat core work skills mahasiswa prodi Manajemen UPI cenderung berada pada kategori yang belum memadai, sehingga program bimbingan karier untuk peningkatan core work skills sangat penting untuk dikembangkan dan diimplementasikan agar mahasiswa memiliki kesiapan diri untuk memasuki dunia kerja. Survey Reardon dkk. (Herr dkk. 1996; Afdal, 2009) menemukan bimbingan karier yang dibutuhkan mahasiswa diantaranya berkenaan dengan informasi pekerjaan, keterampilan yang dibutuhkan, informasi pendidikan yang sedang ditempuh, informasi pengungkapan diri mahasiswa, pelatihan pengambilan keputusan, konseling kelompok berkenaan dengan karier, dan sebagainya. Hal ini tentunya membutuhkan komitmen yang kuat dari seluruh komponen di perguruan tinggi, termasuk pimpinan, dosen dan karyawan, untuk mengembangkan karier mahasiswanya.

\section{METODE}

Penelitian menggunakan pendekatan kuantitatif yaitu suatu jenis penelitian ilmiah di mana peneliti memutuskan apa yang akan diteliti dengan cara mengajukan pertanyaan-pertanyaan yang spesifik atau sempit, mengumpulkan datadata yang dapat dikuantifikasikan, menganalisis angka-angka tersebut dengan menggunakan statistik dan melakukan penelitian dalam suatu cara yang objektif (Creswell, 2012, hlm. 16).

Metode penelitian yang digunakan adalah metode eksperimen kuasi. Penelitian eksperimen kuasi yaitu rancangan penelitian eksperimen tapi tidak dapat berfungsi sepenuhnya untuk mengontrol atau mengendalikan variabelvariabel luar yang dapat mempengaruhi eksperimen. Pada eksperimen kuasi tidak dilakukan dengan teknik random (random assignment) melainkan pengelompokan berdasarkan kelompok yang terbentuk sebelumnya (Creswell, 2012, hlm. 309).

Desain eksperimen kuasi yang digunakan adalah non equivalent control-group design (Borg \& Gall, 2007). Dalam desain ini penentuan partisipan untuk kelompok kontrol dan eksperimen tidak melalui prosedur random assigment, namun kedua kelompok memperoleh pretest dan posttest. Perlakuan (treatment) berupa program bimbingan karier untuk peningkatan core work skills hanya diberikan pada kelompok eksperimen, sedangkan kelompok kontrol tidak mendapat perlakuan.

Populasi penelitian adalah mahasiswa semester akhir Prodi Manajemen UPI. Sampel penelitian ini ditentukan dengan teknik nonprobability random sampling yaitu mahasiswa semester akhir Prodi Manajemen UPI tahun akademik 2014/2015 yang terdiri dari 2 kelas yaitu kelas A berjumlah 35 orang dan kelas B berjumlah 35 orang sehingga secara keseluruhan berjumlah 70 orang (intake group). 


\section{HASIL DAN PEMBAHASAN}

Tabel 1 Efektivitas Program Bimbingan Karier untuk Peningkatan Core Work Skills Mahasiswa Semester Akhir Prodi Manajemen UPI.

\begin{tabular}{cccccc}
\hline Core Work Skills & N & Mean & $\begin{array}{c}\text { Std. } \\
\text { Deviation }\end{array}$ & $\begin{array}{c}\text { Std. Error } \\
\text { Mean }\end{array}$ \\
\hline \multirow{2}{*}{ Posttest } & Kelompok Kontrol & 35 & 204.51 & 23.31 & 3.94 \\
\cline { 2 - 6 } & Kelompok Eksperimen & 35 & 212.86 & 17.33 & 2.93 \\
\hline
\end{tabular}

Tabel di atas menunjukkan skor rata-rata posttest kelompok eksperimen yang diberikan perlakuan program bimbingan karier untuk peningkatan core work skills menunjukkan hasil yang lebih tinggi dibandingkan dengan kelompok kontrol yang tidak diberi perlakuan. Dengan demikian dapat disimpulkan bahwa program bimbingan karir dapat meningkatkan core work skills mahasiswa pada kelompok eksperimen.

Keefektifan program bimbingan karier untuk peningkatan core work skills mahasiswa dapat dilihat dari hasil uji-t. Uji ini dilakukan dengan mambandingkan $t$ hitung dengan $t$ tabel. Jika $t$ hitung lebih besar dari $t$ tabel maka program bimbingan karier efektif untuk peningkatan core work skills mahasiswa dan sebaliknya jika $t$ hitung lebih kecil dari $t$ tabel maka program bimbingan karier tidak efektif untuk peningkatan core work skills mahasiswa.

Berdasarkan 20 indikator core work skills mahasiswa semester akhir Prodi Manajemen UPI, terdapat 18 indikator efektif meningkat setelah dilakukan treatmen. Hal ini menunjukkan program bimbingan karier efektif untuk peningkatan core work skills mahasiswa. Adapun keefektifan program bimbingan karier untuk peningkatan core work skills mahasiswa dapat dijabaran sebagai berikut. Pada indikator komunikasi $t$ hitung sebesar 4,33 dan $t$ table sebesar 2,01 yang berarti thitung lebih besar dari $t$ tabel maka indikator komunikasi efektif meningkat secera signifikan; indikator pemecahan masalah memiliki $t$ hitung sebesar 3,70 dan $t$ tabel sebesar 2,01; berpikir inovatif $t$ hitung 2,59 dan $t$ tabel 2,01; tanggung jawab $t$ hitung 4,34 dan $t$ tabel 2,01; sikap positif terhadap pekerjaan $t$ hitung 3,34 dan $t$ tabel 2,01; efisiensi $t$ hitung 4,72 dan $t$ tabel 2,01; interpersonal $t$ hitung 2,25 dan $t$ tabel 2,01; kerja tim $t$ hitung 3,57 dan $t$ tabel 2,01; citra diri positif $t$ hitung 5,52 dan $t$ tabel 2,01; adaptasi $t$ hitung 3,23 dan $t$ tabel 2,01; fleksibilitas $t$ hitung 2,57 dan $t$ tabel 2,01; antusiasme $t$ hitung 2,90 dan $t$ tabel 2,01; motivasi $t$ hitung 4,26 dan $t$ tabel 2,01; disiplin $t$ hitung 5,19 dan $t$ tabel 2,01; manajemen diri $t$ hitung 5,09 dan $t$ tabel 2,01; rapih $t$ hitung 5,71 dan $t$ tabel 2,01; kejujuran $t$ hitung 4,19 dan $t$ tabel 2,01; dan integritas $t$ hitung sebesar 5,54 dan t tabel sebesar 2,01.

Berdasarkan 18 indikator di atas, memiliki $t$ hitung lebih besar dari $t$ tabel yang menunjukkan program bimbingan karier efektif untuk peningkatan core work skills mahasiswa semester akhir Prodi Manajemen UPI.

Adapun dua indikator core work skills belum berhasil meningkat, yaitu indikator percaya diri dan indikator berkerja tanpa pengawasan. Indikator percaya diri belum meningkat dapat dijelaskan sebagai berikut. Percaya diri merupakan keyakinan dalam diri seseorang mengenai segala aspek kelebihan atau potensi yang dimilikinya dan keyakinan tersebut membuatnya merasa mampu untuk bisa mencapai berbagai tujuan dalam hidupnya. (Hakim, 2005, hlm. 6).

Kepercayaan diri seseorang dapat dipengaruhi oleh dua faktor, yaitu faktor internal dalam diri individu dan faktor eksternal di luar individu. Faktor internal berupa: 1) perasaan takut/gemetar disaat berbicara atau berkomunikasi di hadapan orang banyak (nervous) yang dapat menyebabkan mahasiswa merasa tidak nyaman pada saat mengikuti kegiatan di kelas atau di tempat kerja; 2) adanya perasaan tidak mampu untuk berbuat lebih baik, dalam segala hal (statis); 3) sikap pasrah pada kegagalan, memandang masa depan suram (pessimisme); 4) perasaan kurang dicintai/kurang dihargai oleh lingkungan sekitarnya; 5) selalu berusaha menghindari tugas, tanggung jawab atau pengorbanan; 6) kurang senang dengan keberhasilan orang lain terutama rekan sebaya; 7) sensitivitas batin yang berlebihan, mudah 
tersinggung, cepat marah, dan pendendam; 8) kecemasan mahasiswa dalam menghadapi sesuatu berpengaruh terhadap emosi yang dimiliki sehingga dapat menyebabkan mahasiswa tidak bersemangat pada saat beraktivitas.

Indikator berkerja tanpa pengawasan belum meningkat setelah pemberian perlakuan dapat dijelaskan sebagai berikut. Kemampuan untuk bekerja tanpa pengawasan adalah seseorang yang mampu melaksanakan tugas atau pekerjaan dengan baik kendati tanpa diawasi oleh atasan. Pada penelitian ini, indikator keberhasilan berkerja tanpa pengawasan belum dapat terlihat dikarenakan mahasiswa atau responden belum bekerja sehingga sulit untuk mengukur keefektifan program bimbingan karier yang telah diberikan.

Menurut Faizin, (2014) faktor yang memengaruhi mahasiswa dalam melaksanakan tugas dengan baik dan penuh tanggung jawab adalah keyakinan dalam diri tentang kekuasaan tuhan yang mengetahui seluruh perbuatan manusia dan setiap perbuatan atau pekerjaan yang baik akan diberi balasan berupa pahala dan kebaikan, begitupun sebaliknya perbuatan atau pekerjaan yang tidak baik akan diberi balasan berupa keburukan. Sehingga dengan kata lain seseorang harus selalu dapat melaksanakan tugas atau pekerjaan dengan baik dalam situasi dan kondisi setiap saat baik diawasi maupun tidak diawasi oleh atasan, sehingga berdampak pada keefektifan program bimbingan karier dalam upaya peningkatan kemampuan bekerja tanpa pengawasan sebagai salah satu indikator core work skills.

Pada 18 indikator telah meningkat setelah dilakukan treatmen yang dimulai dari proses eksperientasi, identifikasi, analisis, generalisasi dan hasil evaluasi pada indikator keberhasilan, hal ini ditandai dengan mahasiswa telah mampu dan memiliki keterampilan utama yang dibutuhkan oleh dunia kerja berupa: memperagakan komunikasi dengan efektif; menuliskan dan mengambil sebuah keputusan; menemukan ide-ide kreatif dan inovatif; mengerjakan tugas dengan baik; mengikuti kegiatan sesuai jadwal hingga selesai; menunjukkan kekompakan; dapat bergabung dan ikut serta berdiskusi dengan anggota di kelompok baru; bersikap terbuka dengan gagasan baru; memiliki motivasi; sikap disiplin; menyusun dan menuliskan prioritas; berpenampilan yang rapih; melaksanakan kegiatan sesuai aturan; memiliki moto hidup dan mampu menunjukkan konsistensi antara tindakan dan perkataan.

Peningkatan core work skills menandakan kehandalan program bimbingan karier. Selaras dengan temuan ini hasil penelitian terdahulu juga menunjukkan kehandalan program ini dalam meningkatkan berbagai keterampilan khususnya keterampilan yang dibutuhkan oleh dunia kerja. Keefektifan program bimbingan karier dalam peningkatan core work skills sudah terbukti melaui penelitian yang dilakukan oleh Dartina (2013) yang mengembangkan program bimbingan karier untuk meningkatkan kompetensi komunikasi interpersonal Sales Promotion Girls (SPG). Dartina mengembangkan tujuh tahapan perlakuan untuk meningkatkan kompetensi komunikasi interpersonal dengan tujuan agar SPG mampu bekerja secara profesional dalam hal ini SPG mampu menyampaikan pesan kepada konsumen dilihat dari aspek keterbukaan, empati, dukungan, kepositifan, dan kesamaan pada waktu menawarkan dan menjual produk. Hasil penelitian diperoleh kompetensi komunikasi interpersonal SPG sebesar 27,59\% berada pada kategori sangat kompeten, $74,41 \%$ berada pada kategori kompeten dan tidak ada yang berada pada kategori tidak kompeten dan sangat tidak kompeten.

Program bimbingan karier penting untuk dilaksanakan di perguruan tinggi agar mahasiswa memiliki keterampilan yang dibutuhkan oleh dunia kerja sehingga dapat mempersiapkan diri memasuki dunia kerja. Hal ini senada dengan yang dikemukakan oleh Afdal (2009), pendidikan tinggi dalam hal ini jurusan atau program studi telah mempersiapkan seperangkat paket pembelajaran (kurikulum) pendidikan tinggi yang telah dirancang sedemikian rupa, sehingga mahasiswa yang telah menyelesaikan pendidikannya sudah memiliki keterampilan yang dibutuhkan dunia kerja.

Ahmadi dan Rohani (Pandang dkk. 2010, hlm. 4) mengemukakan bahwa terdapat dua sasaran penting yang hendak dicapai dalam bimbingan karier di perguruan tinggi. Pertama, membantu mahasiswa untuk memahami dan menerima karakteristik dan potensi dirinya. Kedua, membantu mahasiswa memahami dan menyesuaikan diri dengan karakteristik dan tuntutan dunia kerja.

Survey yang dilakukan Reardon dkk. (Herr dkk. 1996; Afdal, 2009) ditemukan 
program bimbingan karier yang dibutuhkan mahasiswa diantaranya berkenaan dengan informasi pekerjaan, keterampilan yang dibutuhkan, informasi pendidikan yang sedang ditempuh, informasi pengungkapan diri mahasiswa, pelatihan pengambilan keputusan, konseling kelompok berkenaan dengan karier, dan sebagainya. Hal ini tentunya membutuhkan komitmen yang kuat dari seluruh komponen di perguruan tinggi, termasuk pimpinan, dosen dan karyawan/staf, untuk mengembangkan karier mahasiswanya.

Walters dan Saddlemire (Herr, 1996; Afdal 2009) menyatakan bahwa $85 \%$ dari mahasiswa Universitas Negeri Green Bowling membutuhkan informasi karier, diantaranya adalah pemahaman diri (potensi diri) untuk memantapkan pilihan pekerjaan yang sesuai dengan penyifatan yang dimilikinya dan pengetahuan serta keterampilan yang dibutuhkan dunia kerja.

Carl D. Perkins Vocational Education Act (Gibson \& Mitchel, 2011, hlm. 447) mengemukakan bimbingan dan konseling karier dapat membantu individu mengembangkan assesmen diri, perencanaan karier, pengambilan keputusan karier, dan pengembangan keterampilan-keterampilan yang dibutuhkan dunia kerja.

Gibson dan Mitchel (2011), menyatakan bahwa pemerintah Amerika Serikat mencanangkan program konseling karier sebagai bantuan karier bagi anak muda atau peserta didik untuk mempersiapkan diri memasuki dunia kerja berupa mengembangkan keahlian dan pengetahuan yang dibutuhkan untuk bisa berpartisipasi penuh di masyarakat dan berhasil di dunia kerja

Bimbingan karier oleh Super (Ahmadi \& Rohani, 1999) diartikan sebagai "proses membantu individu untuk mengembangkan kesatuan dan gambaran diri serta peranannya dalam dunia kerja". Berdasarkan pendapat Super tersebut, ada dua esensi dasar yang terkandung dalam pengertian ini, yaitu: a) proses membantu individu untuk memahami dan menerima diri sendiri; dan b) proses membantu individu memahami dan menyesuaikan diri dengan dunia kerja.

Adapun menurut Person (Sharf, 2010, hlm. 28) bimbingan karier atau dikenal dengan istilah Choosing a Vocation adalah proses: a) memahami dan menerima karakteristik dan potensi diri yang menyangkut bakat, kemampuan, minat, ambisi, dan keterbatasannya; b) memahami dengan jelas tentang dunia kerja, yang menyangkut persyaratan, keterampilan, kondisi kerja, kompensasi, peluang, dan prospek kerja; c) membantu individu (mahasiswa) memahami dan menyesuaikan diri dengan karakteristik pribadi dan tuntutan dunia kerja.

Pelayanan bimbingan karier bertujuan untuk membantu mahasiswa agar memperoleh pemahaman dan penyesuaian diri dalam hubungannya dengan masalah-masalah pekerjaan. Hal tersebut sesuai dengan tujuan bimbingan dan konseling yang terkait dengan aspek karier pada rambu-rambu penyelenggaraan bimbingan dan konseling dalam jalur pendidikan formal oleh ABKIN (Pandang dkk. 2007) yaitu agar peserta didik: a) memiliki pemahaman diri yang terkait dengan pekerjaan; b) memiliki pengetahuan mengenai dunia kerja dan informasi karier; c) memiliki sikap positif terhadap dunia kerja; d) memahami relevansi kompetensi belajar dengan persyaratan pekerjaan yang menjadi citacitanya; e) memiliki kemampuan untuk membentuk identitas karier yaitu mengenal seluk-beluk dunia; f) memiliki kemampuan merencanakan masa depan; g) dapat membentuk pola-pola karier, yaitu kecenderungan arah karier; h) mengenal keterampilan, kemampuan dan minat. Keberhasilan atau kenyamanan dalam suatu karier amat dipengaruhi oleh kemampuan dan minat yang dimiliki; dan i) memiliki kemampuan atau kematangan untuk mengambil keputusan karier.

Holland (Donohue, 2013, hlm. 20) berpendapat bimbingan karier sangat penting bagi peserta didik dalam menentukan pilihan karier, mempersiapkan diri memasuki dunia kerja dan mengetahui informasi kerja berupa: rekrutmen dan seleksi kerja, penempatan kerja, manajemen karier, dan desain pekerjaan.

Program bimbingan karier penting untuk dilaksanakan di perguruan tinggi agar mahasiswa memiliki keterampilan yang dibutuhkan oleh dunia kerja sehingga dapat mempersiapkan diri memasuki dunia kerja. Hal ini senada dengan yang dikemukakan oleh Afdal (2009), pendidikan tinggi dalam hal ini jurusan atau program studi telah mempersiapkan seperangkat paket pembelajaran (kurikulum) pendidikan tinggi yang telah dirancang sedemikian rupa, sehingga mahasiswa yang telah menyelesaikan pendidikannya sudah memiliki keterampilan yang dibutuhkan dunia kerja. 
Ahmadi dan Rohani (Pandang dkk. 2010, hlm. 4) mengemukakan bahwa terdapat dua sasaran penting yang hendak dicapai dalam bimbingan karier di perguruan tinggi. Pertama, membantu mahasiswa untuk memahami dan menerima karakteristik dan potensi dirinya. Kedua, membantu mahasiswa memahami dan menyesuaikan diri dengan karakteristik dan tuntutan dunia kerja.

\section{SIMPULAN DAN SARAN}

Program bimbingan karier efektif untuk peningkatan core work skills mahasiswa. Peningkatan dapat dilihat dari hasil posttest yaitu terdapat 20 indikator core work skills, 18 indikator efektif meningkat dan 2 indikator belum mengalami peningkatan. Peningkatan yang signifikan terjadi pada 18 indikator core work skills yaitu komunikasi, pemecahan masalah, berpikir inovatif, tanggung jawab, sikap positif terhadap pekerjaan, efisiensi, keterampilan interpersonal, bekerja sebagai tim, citra diri yang positif, kemampuan beradaptasi, fleksibilitas, antusiasme, motivasi, disiplin, manajemen diri, rapih, kejujuran, dan integritas.

Sehubungan dengan simpulan di atas, maka diajukan saran sebagai berikut. Bagi perguruan tinggi kajian core work skills sangat penting dan seharusnya mendapat porsi yang sama pentingnya dengan materi kuliah lainnya. Kajian core work skills ini sangat diperlukan bagi kesiapan mahasiswa untuk memasuki dunia kerja khususnya bagi mahasiswa semester akhir. Bagi Dosen dan/atau penasehat akademik, program bimbingan karier ini diharapkan menjadi referensi bagi dosen dan/atau penasehat akademik dalam merencanakan, melaksanakan, dan mengevaluasi layanan bimbingan karier untuk peningkatan core work skills mahasiswa.

Bagi peneliti selanjutnya diharapkan dapat melakukan penelitian dengan pengambilan sampel penelitian dari berbagai program studi untuk dapat menguji keterandalan program bimbingan karier dalam upaya peningkatan core work skills bagi semua mahasiswa semester akhir. Selain menggunakan teknik pengumpulan data berupa kuesioner dan wawancara, hendaknya peneliti selanjutnya dapat menggunakan teknik pengumpulan data yang tepat lainnya seperti observasi langsung, wawancara yang mendalam serta laporan dari dosen maupun orang yang berkaitan langsung dengan subjek penelitian agar dapat mengukur perilaku nyata atau kemampuan core work skills yang sebenarnya dari sampel penelitian. Dari 20 indikator core work skills, 18 indikator efektif mengalami peningkatan dan 2 indikator belum mengalami peningkatan setelah pemberian program bimbingan karier sehingga peneliti selanjutnya dapat mengembangkan pendekatan lain sebagai penunjang dalam meningkatkan 2 indikator core work skills mahasiswa.

\section{DAFTAR RUJUKAN}

Afdal. (2009). Bimbingan Karir di Perguruan Tinggi. [Online]. Diakses dari http://konselingindonesia.com/index.php? option=com_content $\&$ task=view $\&$ id=109 \&Itemid $=104$

Ahmadi, A. \& Rohani, A. (1999). Bimbingan dan Konseling di Perguran Tinggi. Jakarta: PT Rineka Cipta.

Asosiasi Bimbingan dan Konseling Indonesia. (2007). Rambu-rambu penyelenggaraan Bimbingan dan konseling dalam jalur Pendidikan formal. Bandung: ABKIN.

Borg, WR. \& Gall, MD. (2007). Educational Research: An Introduction. Eighth Edition. Boston: Pearson/Allyn \& Bacon.

Brewer, L. (2013). Enhancing Youth Employability: What? Why? and How? Guide to Core WorkSkills. Geneva: International Labour Organization (ILO).

Creswell, JW. (2012). Educational Research: Planning, Conducting, and Evaluating Quantitative and Qualitative Research. Fourth Edition. Boston: Pearson Education, Inc.

Dartina, V. (2013). Program Bimbingan Karier untuk Meningkatkan Kompetensi Komunikasi Interpersonal Sales Promotion Girl (SPG). (Studi Eksperimen Kuasi terhadap Sales Promotion Girl pada Agensi Eta Pro Comm Bandung Tahun 20013). (Tesis). Sekolah Pascasarjana Universitas Pendidikan Indonesia, Bandung.

Donohue, R. (2013). "Holland's constructs in relation to career persistence and career change: A study of Australian managerial and professional workers". Australian Journal of Management, O(0),hlm. 1-23.

Faizin, C. (2014). Berlomba-lomba dalam Kebaikan. [Online]. Diakses dari 
https://indoislamicmedicine.wordpress.co m/2014/01/18/berlomba-lomba-dalamkebaikan/.

Gibson, R. \& Mitchell, M. (2011). Bimbingan dan Konseling. Penerjemah Yudi Santoso. Yogyakarta: Pustaka Pelajar.

Hakim, T. (2005). Mengatasi Rasa Tidak Percaya Diri. Jakarta: Puspa Swara.

Ju, S. dkk. (2012). "Employability Skills Valued by Employers as Important for EntryLevel Employees With and Without Disabilities". JournalCareerDevelopment and Transition for Exceptional Individuals,35(1),hlm. 29-38.

Pandang, A., Aryani, F., \& Simatupang, LF. (2010). Bimbingan Konseling Pendidikan dan Karier untuk SMP, SMA/SMK: Menggunakan Proses Bimbingan Aktif.(Modul). Makassar: ILO \& PPB FIP UNM.

Pandang, A., Sunarty, K., \& Malik, A. (2007) "Penguatan Skema Gender Androgini Mahasiswa: Aplikasi Teori Skema Gender dalam Pengembangan Model Bimbingan Karier Peka Gender di Perguruan Tinggi” Laporan Penelitian Tahun Kedua. Hibah Bersaing DP2M, Ditjen Dikti.

Peraturan Pemerintah (PP). No. 19 tahun 2005 tentang Standar Nasional Pendidikan.

Rahman, A. (2012). Pengaruh Pendidikan Formal - Non Formal dan Informal Terhadap Prestasi Pendidikan. [Online]. Diakses dari http://ariefrahmans.wordpress.com/2012/0 1/01/pengaruh-pendidikan-formal-nonformal-dan-informal-terhadap-prestasipendidikan/.

Sharf, R. S. (2010). Applying Career Develoopment Theory to Counseling. 5th Edition. USA: Brooks/Cole, Cengage Learning.

Undang-undang No. 20 tahun 2003 tentang Sistem Pendidikan Nasional.

Wijayanti, RT. \& Zulaifah, E. (2008). Hubungan antara Efikasi Core Skills dengan Kesiapan Kerja pada Mahasiswa Semester Akhir.(Skripsi). Program Studi Psikologi Fakultas Psikologi dan Ilmu Sosial Budaya Universitas Islam Indonesia, Yogyakarta.

Yana, A. (2013). Pendidikan Menurut Ki Hajar Dewantara. [Online]. Diakses darihttp://asepyana666.blogspot.com/2013 /02/pendidikan-menurut-ki-hajardewantara.html. 